\title{
Integration of biogas plants in the building materials industry
}

\author{
M. Ellersdorfer ${ }^{1, *}$, C. Wei $\aleph^{1}$ \\ ${ }^{1}$ Institute of Process Technology and Industrial Environmental Protection, Mining University Leoben, Austria \\ * Corresponding author. Tel: +4338424025006, Fax: +4338424025002, E-mail: \\ markus.ellersdorfer@unileoben.ac.at
}

\begin{abstract}
The paper quantifies the synergy-effects of an areal combination of biogas-plants with plants of the building materials industry (e.g. cement plants) from the energetic and economical point of view. Therefore a model biogas and cement plant are defined and the effects of a combination of both plants in terms of energetic efficiency, investment and operating costs, greenhouse gas emission reduction and overall energy production costs are quantified. The main benefits of this combination are the utilisation of low temperature excess heat sources from the cement plant for fermenter heating and the direct thermal utilisation of unprocessed biogas as a valuable, $\mathrm{CO}_{2}$-neutral fuel for combustion processes for instance clinker burning. Due to the combination, the energetic efficiency of the biogas plant, defined as utilisable energy output in relation to the energy content of the produced biogas, significantly increases from $63.0 \%$ to $83.8 \%$. Concurrently the energy production costs are reduced, turning biogas into a competitive source of energy without the need for federal sponsorship. Calculations show, that from a plant size of around $90 \mathrm{~m}^{3} \mathrm{sTP} / \mathrm{h}$ biogas production costs in combined plants are even lower than the actual market prize of natural gas.
\end{abstract}

Keywords: biogas, cement plant, thermal utilisation, excess heat recovery

\section{Nomenclature}

volumetric flow rate (standard temperature and pressure). $m^{3}$ STP $/ h$

energy (general) .. $k W h$ electrical energy ....................................... $k W h_{e l}$

thermal energy .......................................... kWh

European currency...................................... $€, \mathrm{ct}$

\section{Introduction}

The anaerobic fermentation of biogenic material presents a well known technology in waste treatment and agriculture. Furthermore the specific production of biogas out of renewable resources provides an opportunity to integrate $\mathrm{CO}_{2}$-neutral energy sources in the power supply chain. Nevertheless state of the art concepts of biogas utilisation like electricity generation in combined heat and power plants (CHPs) or processing of the raw biogas to inject it in existing gas supply systems are still in need of improvement. Energy losses due to processing and compression steps or the production of a significant amount of excess heat reduce the percentage of useable energy from the raw biogas.

In view of this problem, an alternative way of gas utilisation would be desirable. The combination of biogas plants with plants of the building materials industry especially cement plants, presents a unique opportunity to meet these demands [1]. The main benefits are:

- utilisation of excess heat from the cement plant for fermenter heating

- raw biogas as $\mathrm{CO}_{2}$-neutral fuel without the need of processing

- $\quad$ ammonia recovery from the digestate and use as reducing agent in DeNOx-processes

High temperature processes in the cement, lime and magnesia industry are a source of waste heat at various temperature levels. The use of this energy for heating a mesophillic biogas fermenter $\left(\sim 35^{\circ} \mathrm{C}\right)$ allows the utilisation of excess heat at temperature levels beyond $100^{\circ} \mathrm{C}$, which presents a problem for other state-of-the-art solutions. 
The average calorific value of biogas with $21 \mathrm{MJ} / \mathrm{m}^{3}$ (60\% methane, [2]) is sufficient for a direct use as fuel in cement and clinker burning. Primary fuel combustion in the rotary kiln and secondary combustion in the precalciner can be adjusted to work with natural gas as well as biogas [3]. The demands in terms of gas composition for direct burning are not that strict as for CHP plants or injection in natural gas supply systems. Compression of the gas to the pipeline pressure (30 to 80 bar) is not necessary. Hence, raw biogas can be used directly for burning without processing steps like desulphurisation and $\mathrm{NH}_{3}$-removal. $\mathrm{H}_{2} \mathrm{~S}$ in the biogas is oxidised to $\mathrm{SO}_{2}$ during combustion, which reacts to alkalisulphates with the clinker in the preheating and calcining system [4]. The fate of $\mathrm{NH}_{3}$ has to be investigated.

The application of biogas reduces the greenhouse-gas emissions of the cement plant due to the substitution of fossil fuels. On the other hand the combination offers the possibility to improve the partially negative ecobalance of some biogas production ways [5].

The third benefit is the potential recovery of ammonia from the digestate. The output of digestate as a fertiliser for agricultural areas is limited to certain times of the year due to ammonia emissions. Processing of digestate and ammonia recovery can solve the problem of temporal dependency with the concurrent benefit of producing a $\mathrm{NO}_{\mathrm{x}}$-reducing agent for cement plants. By decreasing the ammonium concentration in the effluent for example by steam-stripping, the recycling of the liquid phase into the fermenter might be possible.

\section{Methodology}

To quantify the synergy effects of the areal combination of biogas and cement plants, an Excel-model was developed, in which conventional biogas plants with CHP are compared to the corresponding combined plant in regard to energetic efficiency, $\mathrm{CO}_{2}$-savings, energy production costs and plant feasibility. The biogas plant scale can be adjusted by varying the amount of substrates. For the actual calculations a substrate mix with $90 \%$ manure and $10 \%$ co-substrates (4\% food leftovers, 3\% glycerine and 3\% flotate sludge) was chosen.

The energy balances and costs of combining a conventional biogas plant with a production of $250 \mathrm{~m}_{\text {STP }}^{3} / \mathrm{h}$ respectively $550 \mathrm{~kW}_{\text {el }}$ installed electrical power with a cement plant with a production capacity of $440000 t_{\text {clinker }} / \mathrm{a}$ are presented in detail. Both plants represent a mean plant size in Austria derived from overall production data divided by the number of plants $[6,7]$. In biogas production the trend goes to larger plant sizes, wherefore the mean biogas plant size derived from literature data $(270 \mathrm{~kW}$ el $/$ plant $)$ was doubled. Based on averaged data of numerous existing biogas-plants [8,9] in combination with data from CHP evaluations [10] a basic energy balance for a model biogas-plant was determined. To quantify the main excess heat sources of a model cement plant, the mean thermal energy balance was calculated from averaged literature data for Austrian cement plants [11].

Investment and operating costs of the conventional plant were calculated with four different literature models $[2,9,12,13]$ to prove consistency. The estimations were converted to actual costs on the basis of 2009 by correction with the harmonised index of consumer prices in Austria. The most suited model due to its modular configuration (FNR, 2008) was chosen for the economical comparison of conventional and combined plants. Based on the published FNR-data, compensating curves for specific investment and operating costs were implemented to calculate the scale dependent energy production costs. Investment and operating costs of the combined plant do not comprise expenses for CHP and desulphurisation units but an additional cost factor for the combination (burner, gas pipeline, excess heat utilisation). This factor is made up of fixed costs and scale dependent additional costs 
(investment costs combination in $€=30000+\left(\right.$ actual plant size $\left.\left.\left[\mathrm{m}^{3} \mathrm{sTp} / \mathrm{h}\right] / 500\right) * 100000\right)$. It is assumed that substrate and digestate processing costs are the same for both plants, wherefore these expenses remain unaccounted for.

The determined operating costs together with the depreciation charges result in mean energy production costs in ct/kWh, when divided by the useable energy output. Depreciation charges were calculated on the basis of an annuity factor for 16 years deprication period and an imputed interest rate of $6 \%$. The income of the conventional biogas plant comprises the sale of electricity and thermal energy according to the renewable energy feed-in tariff of the ÖSVO 2010 [14]. In case of the combined plants, the income is considered to result from cost savings for fossil fuels (natural gas and fuel oil) [15] and $\mathrm{CO}_{2}$-savings valuated with an actual emission certificate price of $15 € / t \mathrm{CO}_{2}$. Electrical energy to cover the internal demand of the combined plant has to be bought on the market [16]. Based on these data the ROI and payback-period for the conventional and combined plant can be calculated.

The determination of the $\mathrm{CO}_{2}$-savings is based on a representative mixture of cement plant fuels from literature [6]. It is assumed, that first natural gas and then fuel oil are replaced by biogas, as far as the produced amount of biogas can cover the demands of these fuels. Mean $\mathrm{CO}_{2}$-savings were calculated from literature data for $\mathrm{CO}_{2}$-emission rates of fossil fuels [17]. The electrical energy demand of the combined plant is covered by electricity from national power networks, which decreases the $\mathrm{CO}_{2}$-savings due to emission of greenhouse gases during the production of conventional electrical energy [18].

\section{Results}

The basic energy balance of a $250 \mathrm{~m}^{3} \mathrm{STP} / \mathrm{h}$ model biogas plant is visualised in figure 1 .

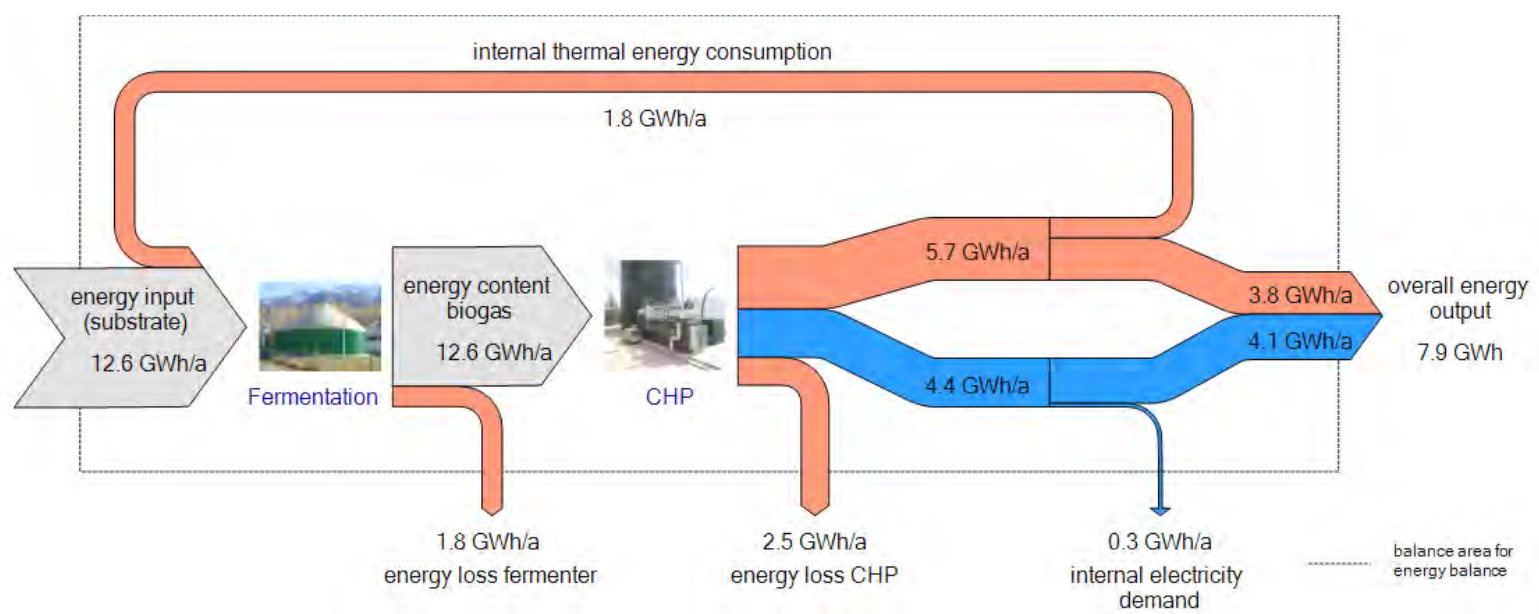

Fig. 1. Energy balance of a conventional biogas plant $\left(250 \mathrm{~m}^{3} \mathrm{STP} / \mathrm{h}\right)$ with combined heat and power unit (CHP, $550 \mathrm{kWh}_{\text {el }}$ installed electrical power); for detailed data see table 2.

Figure 1 shows that only 35\% of the input energy of $12.6 \mathrm{GWh} / \mathrm{a}$ can be converted to electrical energy with 45\% low temperature excess heat from the CHP. After deduction of the internal electrical and thermal energy demand, 30.5\% thermal energy and 32.5\% electrical energy remain, giving an overall energetic plant efficiency of $63 \%$. The high amounts of energy needed for fermenter heating and a CHP efficiency of $80 \%$ significantly decrease the overall plant efficiency. Moreover, this calculation represents the ideal case, where $100 \%$ of the available thermal energy is utilised for example for drying processes or district heating. 
The thermal energy balance of the model cement plant (440 $000 \mathrm{t}_{\text {clinker }} / \mathrm{a}$ ) is visualised in figure 2 .
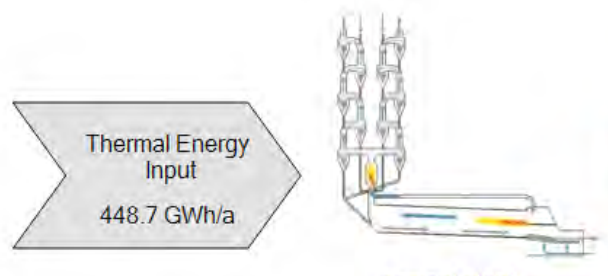

cement plant

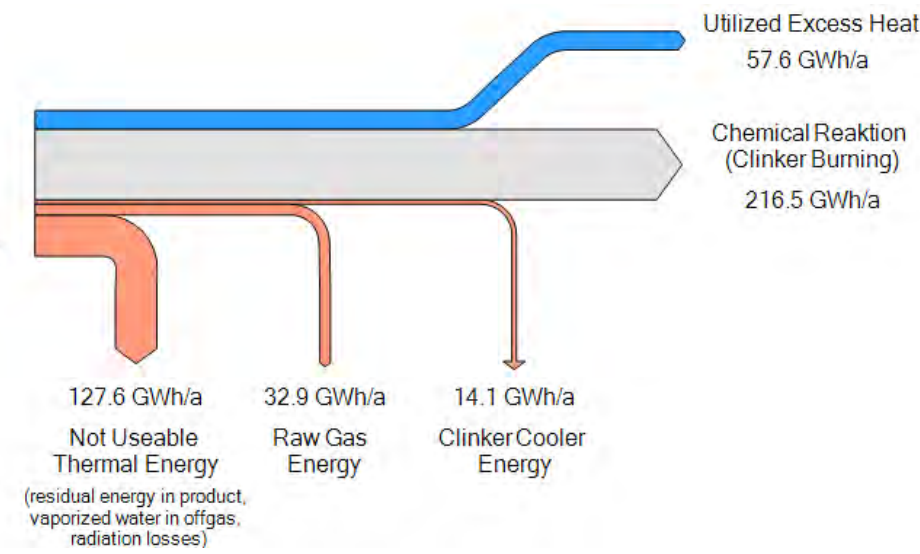

radiation losses)
restized water in offget

Fig. 2. Thermal energy balance of a conventional cement plant (440000 $\left.t_{\text {clinker }} / a\right)$

Not useable thermal energy like the remaining energy content in the product, vaporised water in the offgas and thermal radiation turn out to be the main excess heat sources. The residual energy in the cooling air after the clinker cooler and the energy in the raw gas after the raw mill can easily be utilised for fermenter heating by adequate heat recovery concepts, for example the installation of gas/fluid heat exchangers as shown in figure 3.

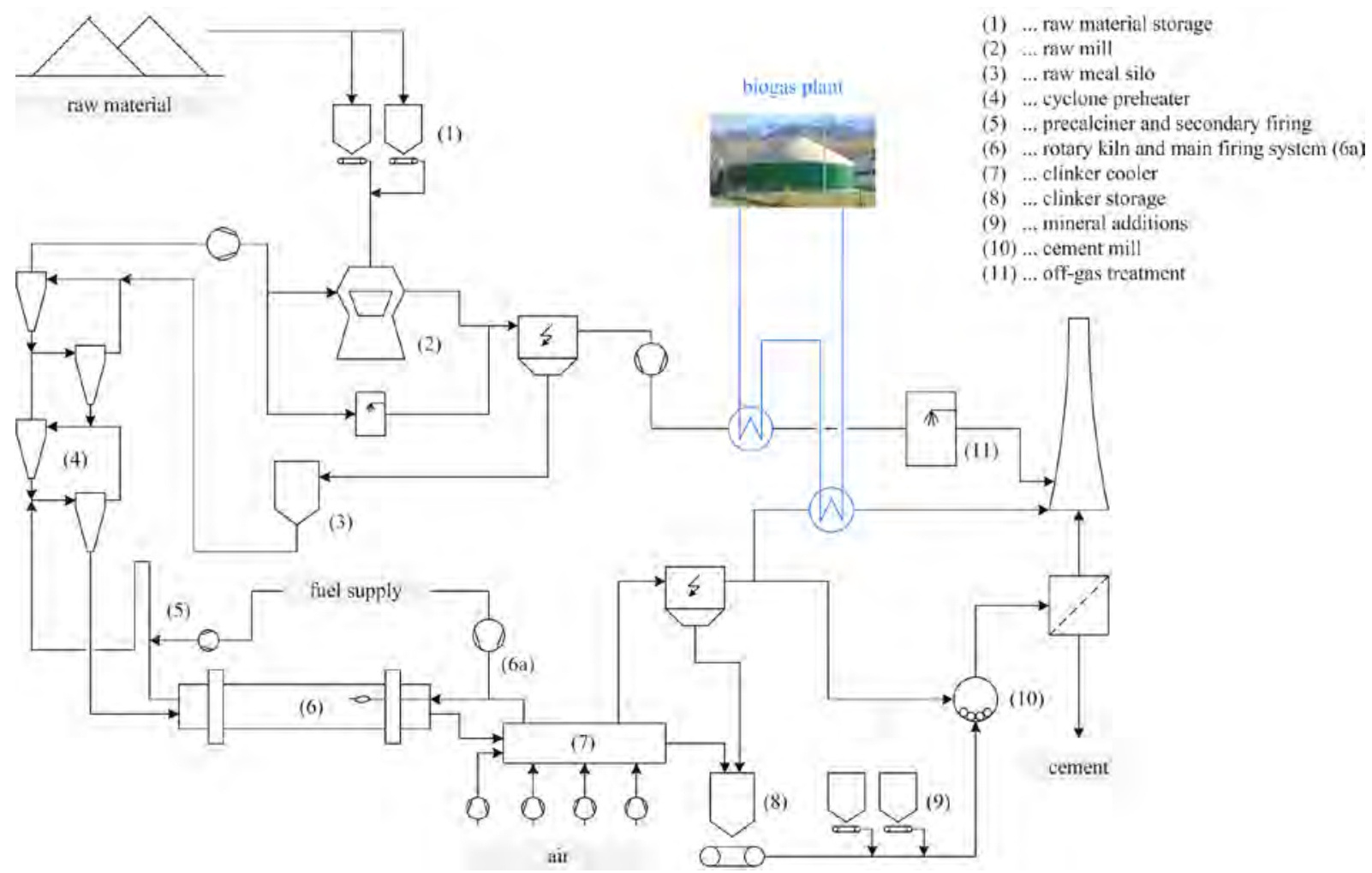

Fig. 3. Process flowchart of a combined biogas and cement plant.

Figure 4 illustrates the effects of this combination on the energy balance of a $250 \mathrm{~m}^{3} \mathrm{sTP} / \mathrm{h}$ biogas plant. Clinker cooler and raw gas excess energy together offer nearly the 27-fold amount of energy needed for fermenter heating. Electrical energy has to be bought in addition. The direct use of raw biogas enhances the utilisable energy of the biogas plant, 
leading to a major increase from 63.0 to $83.8 \%$ in the overall plant efficiency (cf. table 2). The thermal efficiency of the cement plant only slightly increases from 61.3 to $61.5 \%$ due to its large excess heat production compared to the energy demand of the biogas plant. On the basis of the above defined plants scales, $2.7 \%$ of the thermal energy consumption of the cement plant can be replaced by raw biogas, resulting in a decrease in greenhouse gas emissions of around $2860 \mathrm{t} \mathrm{CO}_{2} / \mathrm{a}$ or $0.8 \%$ of the annual $\mathrm{CO}_{2}$-emissions of the cement plant.

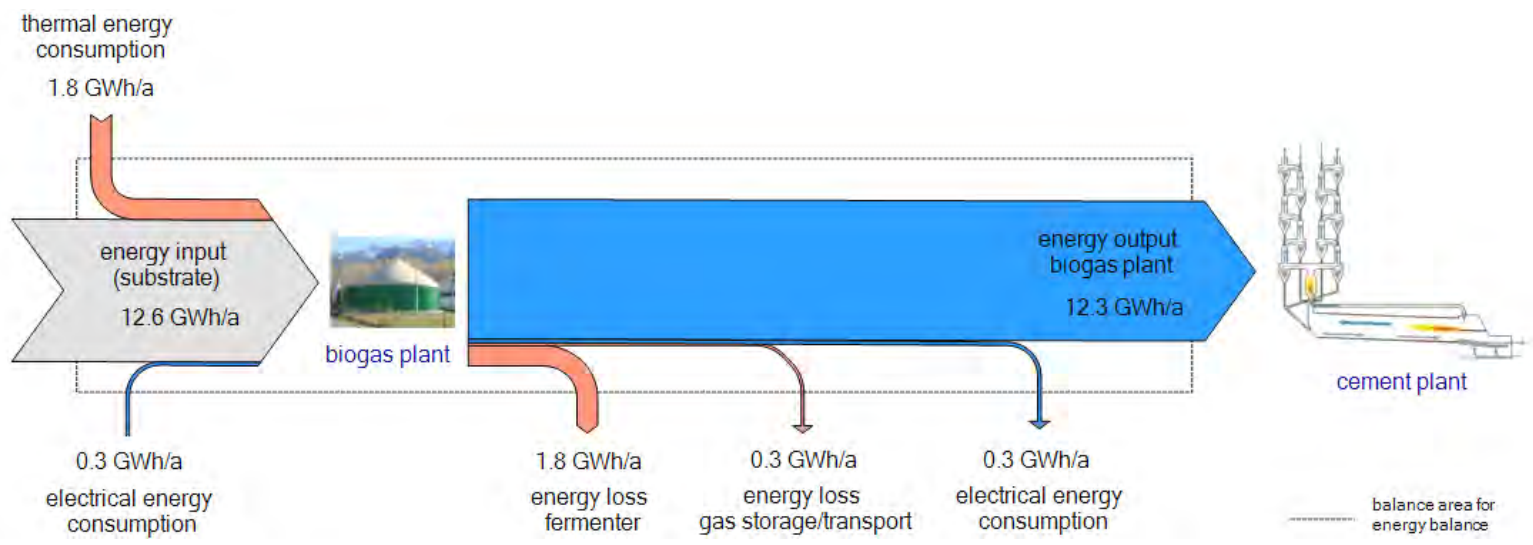

Fig. 4. Energy balance of a combined plant; biogas plant $\left(250 \mathrm{~m}^{3}\right.$ sтр $\left./ \mathrm{h}\right)$ coupled with a cement plant (440 $\left.000 t_{\text {clinker }} / a\right)$

Table 1 comprises the estimated investment costs for a conventional biogas plant $\left(250 \mathrm{~m}^{3} \mathrm{sTP} / \mathrm{h}\right)$ with biogas utilisation via a CHP. The results of the models generally fit together, with the FNR model being the closest to the mean investment costs of $1,750,819 €$ derived from all models.

Table 1. Investment costs for a conventional biogas plant ( $250 \mathrm{~m}^{3}$ STP $\left./ \mathrm{h}\right)$ based on different models

$\begin{array}{cccc}\text { FNR } & \text { KTBL } & \text { LfU Bayern } & \text { Hornbacher }^{*} \\ {[12]} & {[9]} & {[2]} & {[13]}\end{array}$

\begin{tabular}{cccccc}
\hline plant investment costs & {$[€]$} & $1,172,538$ & 943,757 & - & $1,578,733$ \\
CHP investment costs & {$[€]$} & 493,729 & 626,819 & - & 336,284 \\
total investment costs & {$[€]$} & $\mathbf{1 , 6 6 6 , 2 6 7}$ & $\mathbf{1 , 5 7 0 , 5 7 7}$ & $\mathbf{1 , 8 5 1 , 4 1 4}$ & $\mathbf{1 , 9 1 5 , 0 1 7}$ \\
\hline
\end{tabular}

* estimation excl. CHP, CHP costs estimated with different model (ASUE [10])

Table 2 shows the results of the energy balance as well as the energy production costs and plant feasibility calculations of a conventional plant compared with the combined alternative.

Investment and operating costs of the combined plant are considerably lower because of the missing CHP plant. Together with the higher amount of energy output in terms of fuel, the production costs of energy in a combined plant are around $3.2 \mathrm{ct} / \mathrm{kWh}$ compared to $7.0 \mathrm{ct} / \mathrm{kWh}$ for a conventional plant, in which $100 \%$ of the thermal energy output of the CHP are utilised. Electricity production costs without thermal energy utilisation are $13.5 \mathrm{ct} / \mathrm{kWh} \mathrm{h}_{\mathrm{el}}$. The ROI of the combined plant is somewhat higher and the payback period shorter because of the lower investment and operating costs compared to the conventional plant. 
Table 2. Base data of a conventional biogas plant compared with an equally scaled combined plant

\begin{tabular}{cccc}
\hline & & FNR & FNR \\
& & conventional plant & combined plants \\
\hline biogas production & {$\left[\mathrm{m}^{3} \mathrm{sTp} / \mathrm{h}\right]$} & 250 & 250 \\
plant energy input & {$[\mathrm{kWh} / \mathrm{a}]$} & $12,580,295$ & $14,718,946$ \\
electrical energy output & {$[\mathrm{kWh} / \mathrm{el}]$} & $4,088,596$ & 0 \\
thermal energy output & {$\left[\mathrm{kWh}_{\mathrm{th}} / \mathrm{a}\right]$} & $3,836,990$ & 0 \\
utilisable energy output & {$[\mathrm{kWh} / \mathrm{a}]$} & $7,925,586$ & $12,328,689$ \\
overall plant efficiency & {$[\%]$} & $\mathbf{6 3 . 0}$ & $\mathbf{8 3 . 8}$ \\
\hline total investment costs & {$[€]$} & $1,666,267$ & $1,175,732$ \\
operating costs & {$[€ / \mathrm{a}]$} & 387,181 & 281,055 \\
annual depreciation & {$[€ / \mathrm{a}]$} & 164,881 & 116,341 \\
total variable costs & {$[€ / \mathrm{a}]$} & 552,062 & 397,396 \\
energy production costs* & {$[\mathrm{ct} / \mathbf{k W h}]$} & $\mathbf{7 . 0}$ & $\mathbf{3 . 2}$ \\
electrical energy costs & {$[\mathrm{ct} / \mathrm{kWh} \mathrm{el}]$} & 13.5 & - \\
\hline cost savings fossil fuels & {$[€ / \mathrm{a}]$} & 0 & 471,895 \\
cost savings CO ${ }_{2}$-emissions & {$[€ / \mathrm{a}]$} & 0 & 45,598 \\
electrical energy income & {$[€ / \mathrm{a}]$} & 506,986 & 0 \\
thermal energy income & {$[€ / \mathrm{a}]$} & 92,088 & 0 \\
total income & {$[€ / \mathrm{a}]$} & 599,074 & 517,494 \\
total profit & {$[€ / \mathrm{a}]$} & 47,012 & 120,098 \\
ROI (profit/investment) & {$[\%]$} & 2.8 & 10.2 \\
payback period & {$[\mathrm{a}]$} & 11.0 & 6.1 \\
(debt-repayment method) & & & \\
\hline *100\% utilisation of thermal energy & & &
\end{tabular}

The depiction of the energy production costs of the conventional and combined plant over the plant scale shows the typical decrease in production costs with increasing plant size (figure 5).

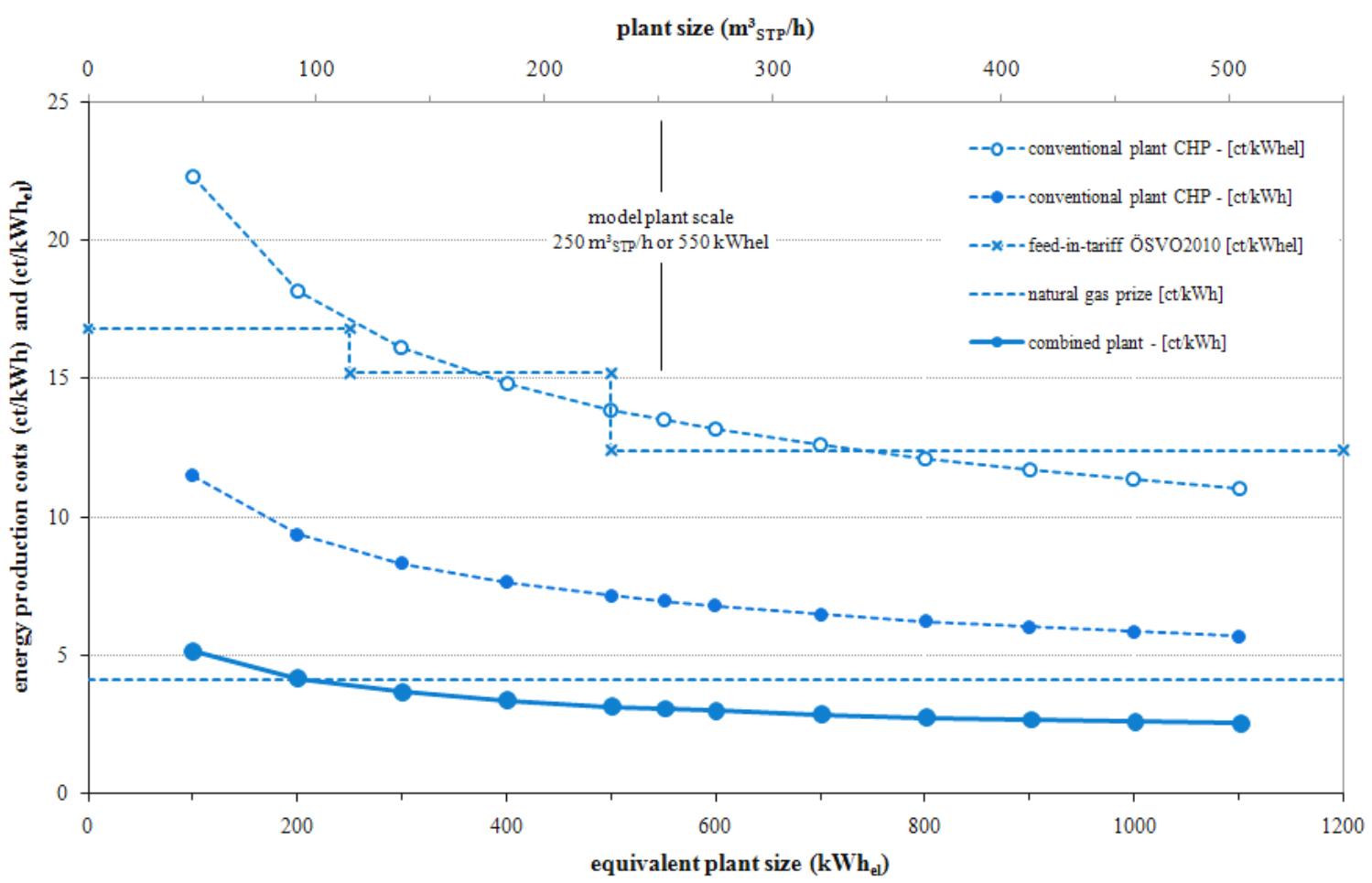

Fig. 5. Energy production costs (electrical and thermal energy) for various plant sizes. 
Conventional biogas plants without thermal energy utilisation have electrical energy production costs from 20 to $12 \mathrm{ct} / \mathrm{kWh}_{\mathrm{el}}$. The simultaneous use of $100 \%$ of the CHPs thermal energy output can decrease the energy production costs to values between 11 and $6 \mathrm{ct} / \mathrm{kWh}$ but is difficult to implement. Compared to the feed-in-tariff in accordance with the ÖSVO 2010 [14] one can see, that the combined use of thermal energy is essential for the feasibility of a conventional biogas plant. The energy production costs of combined plants $(\sim 5$ and 2.5 $\mathrm{ct} / \mathrm{kWh}$ ) are well below conventional plants due to the higher amount of energy utilised as fuel for clinker burning. From a plant size of $200 \mathrm{kWh}$ el $\left(\sim 90 \mathrm{~m}^{3} \mathrm{STP} / \mathrm{h}\right)$ the production costs of biogas in combined plants actually fall below the costs for natural gas [20].

\section{Conclusions}

The combination of a biogas plant with a cement plant is a possibility to significantly increase the overall efficiency of a biogas plant. The use of unprocessed biogas as a fuel for clinker burning and the utilisation of excess heat from the cement plant enables biogas costs to be competitive to natural gas costs even without federal sponsorship.

Nevertheless, there are still points that have to be investigated, first and foremost the fate of $\mathrm{H}_{2} \mathrm{~S}$ and $\mathrm{NH}_{3}$ in the clinker burning process and their contribution to NOx and $\mathrm{SO}_{2}$ emissions of the cement plant. Moreover, solutions for the gas utilisation during maintenance periods of the cement plant have to be found. Whereas these periods might also be used for servicing the biogas plant, concepts must be developed for a controlled diminishing of the biogas production rate by reducing or altering the substrate feed and concurrent burning of biogas. Thereby, the internal thermal energy demand of the biogas plant can be covered temporarily.

The recovery of ammonia from the digestate for DeNOx-processes would be a major benefit for the cement plant. Potential technical solutions like steam-stripping of liquid digestate have to be investigated. Especially substrates with the potential to cause ammonia inhibition of the fermentation process might be processed in combined plants, if ammonia recovery is feasible. The practicability also strongly depends on the type of substrates, which have to be suited for fermentation but not for direct burning. Important parameters for waste fuels in cement plants are calorific value along with the content of water, ash, sulphur, chlorine and heavy metals as well as the suitability for the burners [3]. Examples for substrates with limited applicability are liquid manure and brewery and agricultural residues due to the high water content. The inhomogeneity of food residues as well as slaughterhouse waste and similar materials impede direct burning, but otherwise present wastes high in biogas production.

Due to sufficiently available waste heat energy and the huge fuel consumption of cement plants, the share of fuel provided by biogas can be increased almost arbitrarily, resulting in cheaper biogas production costs and significant $\mathrm{CO}_{2}$-savings. One $2 \mathrm{MW}$ biogas plant can substitute over $10 \%$ of the energy consumption of a $440000 t_{\text {clinker }} / \mathrm{a}$ cement plant and save around $13000 \mathrm{t} \mathrm{CO}_{2} / \mathrm{a}$. The substitution is only limited by the available amount of substrates for the biogas plant. Nevertheless, also small scale options are possible, because any industrial plant with high temperature processes and utilisable excess heat, high fossil fuel consumption and the need of a denitrification system is a potential site where biogas plants can be installed. In many cases this combination would be the better alternative compared to biogas plants in the open countryside. With the developed model, site specific questions like maximum substrate and transport costs for economical plant operation can be estimated. Thereby, the number of potential biogas plant sites increases and the role of biogas as $\mathrm{CO}_{2}$-neutral fuel in power supply can be strenghtened due to the installation of sustainable energy systems. 


\section{References}

[1] M. Ellersdorfer, W. Kepplinger, Utilisation of Biogas, in: 13th International Tuzla Summer University, Symposium Rational Energy Usage, Energetic Efficiency and Sustainable Ecological Development, 2008, p. 45 - 48.

[2] Bayerisches Landesamt für Umwelt (Hrsg.), Biogashandbuch Bayern - Materialienband, Kap. 1.7, Stand Mai 2007, p. 20.

[3] European IPPC Bureau (Hrsg.), Reference Document on Best Available Technique in the Cement, Lime and Magnesium Oxide Manufacturing Industries, Feb. 2009, pp. 26 - 32.

[4] Verein Deutscher Zementwerke e.V., Umweltdaten der deutschen Zementindustrie 2009, 11. Ausgabe, 2010, p. 21.m

[5] R. Zah et. al., Ökobilanz von Energieprodukten: Ökologische Bewertung von Biotreibstoffen, Schlussbericht, Empa (Hrsg.), 2007, pp. 92 - 94.

[6] G. Mauschitz, Emissionen aus Anlagen der österreichischen Zementindustrie Berichtsjahr 2009, Vereinigung der österreichischen Zementindustrie (Hrsg.), 2010, p. 4.

[7] B. Baumgartner, M. Kupusovic, H.T. Blattner, National Report on current status of biogas/biomethane production - AUSTRIA, WP5 - deliverable 5.1, Feb. 2010, p. 4.

[8] Fachagentur Nachwachsende Rohstoffe e.V. (Hrsg), Biogas-Anlagen, 12 Datenblätter, www.fnr.de, 2004, pp. 7 - 39.

[9] H. Döhler et. al., Faustzahlen Biogas, Kuratorium für Technik und Bauwesen in der Landwirtschaft e.V. (Hrsg.), 2. Auflage, 2009, p. 187 - 199.

[10]ASUE Arbeitsgemeinschaft für sparsamen und umweltfreundlichen Energieverbrauch e.V. (Hrsg), BHKW-Kenndaten 2005, Verlag rationeller Erdgaseinsatz, 2005, p. 14.

[11]H. Berger, V. Hoenig, Energieeffizienz der österreichischen Zementindustrie, Vereinigung der österreichischen Zementindustrie (Hrsg.), 2010, pp. 18 - 44.

[12] Institut für Energetik und Umwelt GmbH, Studie Einspeisung von Biogas in das Erdgasnetz, Fachagentur Nachwachsende Rohstoffe e.V. (Hrsg), 2. Auflage 2006, pp. $127-159$.

[13]D. Hornbacher, Online Planung einer Anlage zur Biogas-Netzeinspeisung, www.biogasnetzeinspeisung.at, 2010.

[14]Bgbl.II Nr.42/2010, Ökostromverordnung 2010 - ÖSVO 2010 Teil II, www.ris.bka.gv.at.

[15] Statistik Austria (Hrsg.), Jahresdurchschnittspreise und -steuern für die wichtigsten Energieträger 2009, www.statistik.at, 2009, pp. 1.

[16]Energie-Control GmbH (Hrsg.), Auswertung der Industriepreiserhebung Strom Jänner 2010, www.e-control.at, 2010, pp. 2.

[17]Bayerisches Landesamt für Umwelt (Hrsg.), Leitfaden für effiziente Energienutzung in Industrie und Gewerbe, 2. überarbeitete Auflage, Stand November 2009, p. 27.

[18] International Energy Agency, $\mathrm{CO}_{2}$ Emissions from Fuel Combustion Highlights, IEA Statistics, 2010 Edition, p. 107.

[20]Energie-Control GmbH (Hrsg.), Auswertung der Industriepreiserhebung Gas Jänner 2010, www.e-control.at, 2010, p. 2. 